\title{
Strain and strain rate analysis of the right ventricle in patients with hypoplastic left heart syndrome
}

Andrew W Hoyer ${ }^{*}$, Thomas L Ratchford, Jiade Yu

From 2011 SCMR/Euro CMR Joint Scientific Sessions

Nice, France. 3-6 February 2011

\section{Introduction}

Assessment of right ventricular (RV) function in patients with hypoplastic heart syndrome (HLHS) is essential, but echocardiographic assessment remains largely subjective and $\mathrm{RV}$ volume quantification by CMR is time consuming.

\section{Purpose}

To determine whether software designed for analysis of echocardiograms can be adapted to evaluate strain and strain rate of the RV in CMR images from patients with HLHS.

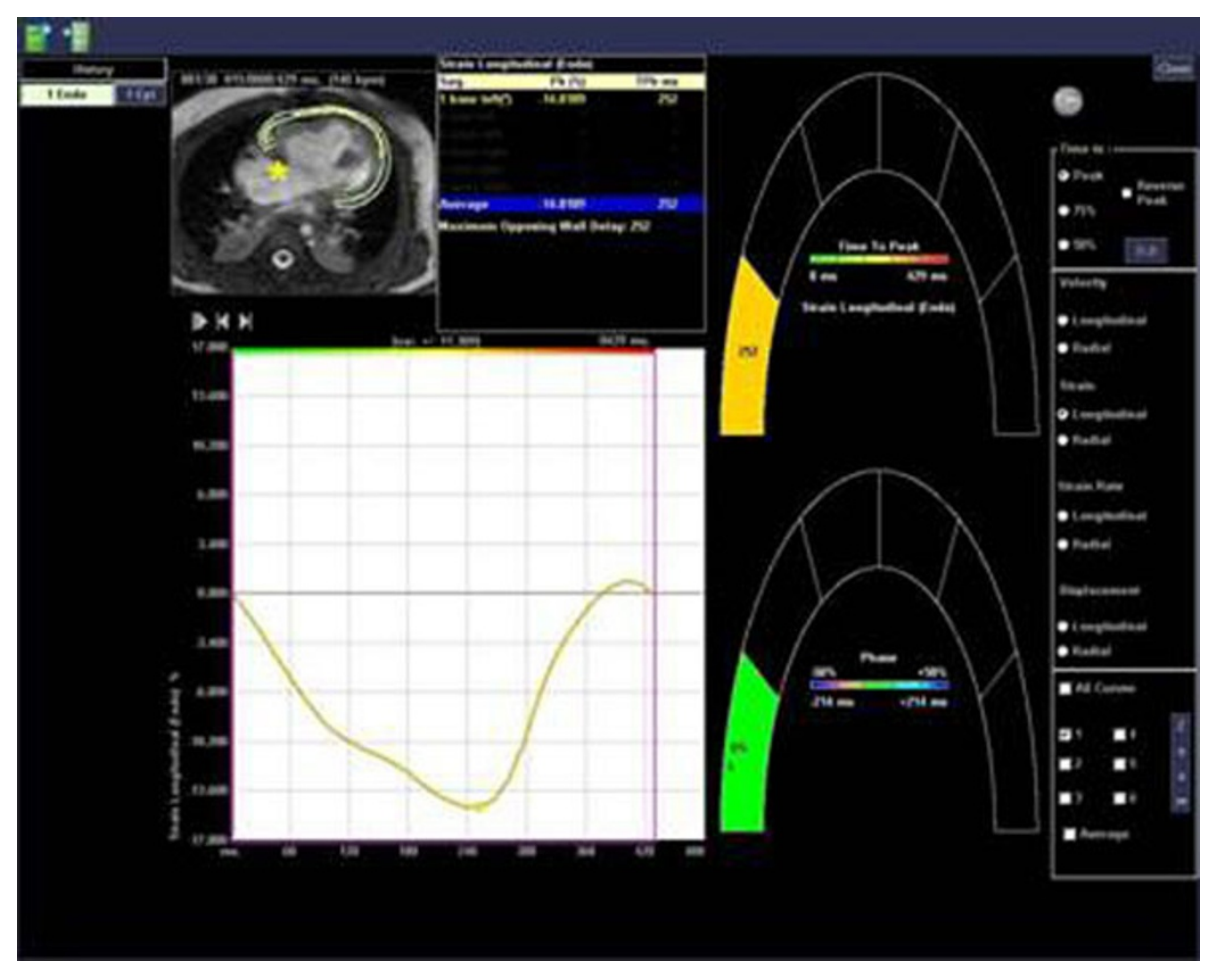

Figure 1 Screen shot from analysis program; curve of longitudinal strain is shown. 


\section{Methods}

Axial SSFP cine images from 10 patients status post Norwood-Sano procedure were analyzed using Siemens Vector Velocity Imaging software after each study's DICOM header had been modified. Longitudinal and radial strain and strain rate were calculated for the segment of RV myocardium at the right AV groove. 6 patients were female; median age was 3 months; mean weight was $5.5 \mathrm{~kg}$.

\section{Results}

The mean longitudinal strain of the $\mathrm{RV}$ at the $\mathrm{AV}$ groove is $-7.1 \%$ while the mean strain rate is $-0.9 \mathrm{~s}^{-1}$; the mean radial strain is $3.1 \%$ and the mean strain rate is $-1.4 \mathrm{~s}^{-1}$. Figure 1

\section{Conclusions}

Indices of myocardial performance (strain and strain rate) can be analyzed from SSFP cine images using a program designed to evaluate echocardiograms, offering the potential for improved assessment of the RV in patients with HLHS.

Published: 2 February 2011

doi:10.1186/1532-429X-13-S1-P207

Cite this article as: Hoyer et al: Strain and strain rate analysis of the right ventricle in patients with hypoplastic left heart syndrome. Journal of Cardiovascular Magnetic Resonance 2011 13(Suppl 1):P207.

Submit your next manuscript to BioMed Central and take full advantage of:

- Convenient online submission

- Thorough peer review

- No space constraints or color figure charges

- Immediate publication on acceptance

- Inclusion in PubMed, CAS, Scopus and Google Scholar

- Research which is freely available for redistribution

Submit your manuscript at www.biomedcentral.com/submit
C Biomed Central 